Geographic distribution of Sarcoporia polyspora and S. longitubulata sp. nova

\title{
Vlasak, Josef
}

2015-03

Vlasak , J , Vlasak Jr. , J , Kinnunen , J \& Spirin , V 2015 , ' Geographic distribution of Sarcoporia polyspora and S. longitubulata sp. nova ' , Mycotaxon , vol. 130 , pp. 279-287 . https://doi.org/10.5248/13

http://hdl.handle.net/10138/159408

https://doi.org/10.5248/130.279

publishedVersion

Downloaded from Helda, University of Helsinki institutional repository.

This is an electronic reprint of the original article.

This reprint may differ from the original in pagination and typographic detail.

Please cite the original version. 


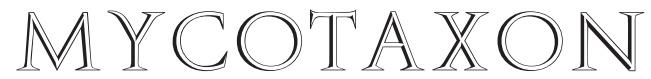

Volume 130, pp. 279-287

http://dx.doi.org/10.5248/130.279

January-March 2015

\section{Geographic distribution of Sarcoporia polyspora and S. longitubulata sp. nov.}

JOSEF VLASÁK ${ }^{1 *}$, JOSEF VlasÁK JR.,

JUHA KinNUnen², \& ViaCHESLAV SPIRIN ${ }^{2}$

${ }^{1}$ Biol. Centre of the Academy of Sciences of the Czech Republic,

Branišovská 31, CZ-370 05 České Budějovice, Czech Rep.

${ }^{2}$ Botanical Museum, P.O. Box 7, FI-00014 University of Helsinki, Finland

* CORRESPONDENCE TO: vlasak@umbr.cas.cz

ABSTRACT - DNA study of Sarcoporia polyspora (= Parmastomyces transmutans) revealed only negligible sequence differences between conifer-dwelling specimens with cartilaginous layer in the context from USA, Brazil, Europe, and Far East Asia, but a very different sequence from three resupinate and hardwood-bound collections without such a layer and with slightly narrower and pale brown spores from USA and Madeira Islands. This fungus, found also among historical USA collections of S. polyspora in the BPI herbarium, is described here as Sarcoporia longitubulata. The phylogenetic position of Sarcoporia is discussed.

Key words - Basidiomycota, brown rot fungi, molecular taxonomy, Parmastomyces kravtzevianus

\section{Introduction}

Sarcoporia polyspora P. Karst. is a very distinct, brown-rot polypore with soft, resupinate to effused-reflexed basidiomes that are white to crème at first but turn reddish-brown after bruising or drying. It can be easily recognized by its ellipsoid and thick-walled, dextrinoid spores, which are quite unique in polypores. The species is rare in Europe but rather common in North America (on Tsuga spp. and Pinus spp.) and in Asia (Vlasák \& Kout 2010, Dai 2012). The fungus was described by Karsten (1894) but Karsten's name was abandoned for years. Based on collections from Estonia and Siberia, it was independently described by Parmasto (1957) as Tyromyces kravtzevianus Bondartsev \& Parmasto, and a few years later Kotlaba \& Pouzar (1964) created the genus Parmastomyces for this unique polypore. In the USA, Overholts (1941) described this species (invalidly, without a Latin diagnosis) as "Polyporus subcartilagineus." Later he described still another species, Polyporus 
transmutans Overh., which he distinguished by the more distinctly pileate habit and its growth on Prunus (Overholts 1952). Ryvarden \& Gilbertson (1984), who found the type of $P$. transmutans identical with "P. subcartilagineus" as well as with European specimens of Parmastomyces kravtzevianus, coined the name Parmastomyces transmutans (Overh.) Ryvarden \& Gilb. for all collections with typical spores. Niemelä et al. (2005), however, studied Karsten's type material and re-established the oldest name, Sarcoporia polyspora, for this species.

Somewhat aberrant morphology of some recent collections from hardwood hosts and conifers led us to question the identity of Eurasian/American and of hardwood/conifer-inhabiting Sarcoporia. We have sampled European, American, and Asian collections from conifers and hardwoods and also studied the type of Polyporus transmutans from the BPI herbarium along with several other American BPI collections determined as P. transmutans to explore whether or not all these specimens represent the same species.

\section{Materials \& methods}

\section{Morphological study}

The studied specimens are deposited in the US National Fungus collection, Beltsville, USA (BPI), in private herbarium of J. Vlasák (JV), and in mycological herbarium of Finnish Museum of Natural History, University of Helsinki, Finland (H). They were examined from slides prepared in cotton blue (CB) and Melzer's reagent (IKI) with a Leitz Diaplan microscope ( $\times 1250$ magnification). Measurements were done in cotton blue using phase contrast illumination and oil immersion (with a subjective accuracy of $0.1 \mu \mathrm{m}$; Miettinen et al. 2006). For presenting the size range of basidiospores, $5 \%$ of the measurements were excluded from each end of the range and are given in parentheses. The following abbreviations are used: $\mathrm{L}^{\prime}=$ basidiospore length, $\mathrm{L}=$ mean basidiospore length (arithmetical average of all basidiospores), $\mathrm{W}^{\prime}=$ basidiospore width, $\mathrm{W}=$ mean basidiospore width (arithmetical average of all basidiospores), $\mathrm{Q}=\mathrm{L}^{\prime} / \mathrm{W}^{\prime}$ ratio range, and $\mathrm{n}=$ the number of basidiospores measured from given number of specimens. $\mathrm{KOH}-$ indicates unchanged in 5\% KOH and IKI- indicates unchanged in Melzer's reagent.

\section{Molecular phylogeny}

DNA isolation and nrDNA ITS region sequencing methods follow Vlasák \& Kout (2011). The sequences were aligned with Clustal X and manually pruned. Evolutionary analyses were conducted in MEGA6 (Tamura et al. 2013) using "all sites" and "uniform rates" options. Other options, such as "complete deletion" and "gamma distributed with invariant sites," and all their combinations provided virtually identical phylogeny.

\section{Results}

\section{Phylogenetic analysis}

Sarcoporia specimens collected on hardwoods and conifers in the USA, Madeira Island, Czech Republic, and European and Far East Russia were 


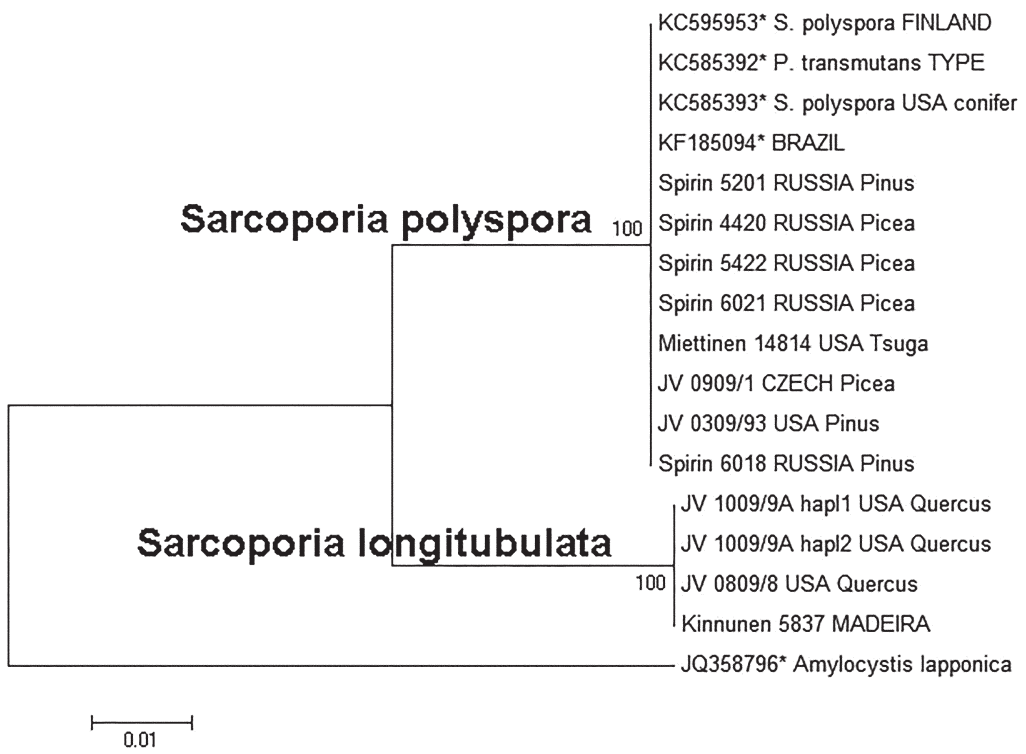

FIGURE 1: Phylogenetic relationships of 15 Sarcoporia specimens inferred from ITS rRNA sequences. Amylocystis lapponica was used as outgroup. Topology from maximum likelihood (ML) analysis. Support values along branches from ML bootstrap (1000 replicates). Branch lengths are drawn proportional to the number of substitutions per site. GenBank numbers with asterisk indicate sequences retrieved from GenBank; other GenBank numbers in Specimens examined.

sequenced and compared with Sarcoporia sequences in GenBank. A total of 14 ITS and 2 nucLSU sequences were newly generated for this study and deposited in GenBank. The ITS dataset comprising 16 sequences resulted in an alignment with 653 characters, of which 81 were variable and 30 parsimony informative. Extremely high sequence conservation could be demonstrated among all conifer-dwelling specimens from different continents, with Eurasian specimens differing from American in only one base insertion in ITS1 and some specimens showing two haplotypes, with and without this insertion (not shown in FIG. 1). On the other hand, most of hardwood-dwelling specimens showed a very different sequence with about 40 mutations in ITS region. Similarly large sequence differences were found with the nucLSU sequence dataset (not shown), using only two sequences from each species. The aberrant hardwood specimens were also characterized by very thick and soft resupinate basidiocarps with long tubes and thin subiculum without cartilaginous layer. They are described below as a new species, S. longitubulata. 


\section{Taxonomy}

Sarcoporia longitubulata Vlasák \& Spirin, sp. nov.

MycoBank MB 809624

Sarcoporiae polysporae similis, sed tubulis longis et sporis coloratis.

TyPe: USA, Pennsylvania: Phoenixville, Schuylkill Canal, Ravine Trail, log of Quercus, 2 Sep 2008, J. Vlasák JV 0809/8 (Holotype, BPI 892956; isotypes, JV, H; GenBank, KM207860, KM207863).

ЕтумоLоgy: longitubulata (Lat.), referring to the very long tubes found in most of the collected specimens.

BAsidiomes annual, resupinate, pulvinaceous, up to $20 \mathrm{~cm}$ long, $15 \mathrm{~cm}$ wide, and $2 \mathrm{~cm}$ thick, strikingly soft to downy, drying brittle; margin whitish to crème, about $1 \mathrm{~mm}$ broad, soft and cottony, later indistinct; pore surface at first crème with reddish tints, distinctly reddish-brown after bruising, brown to blackish-brown on drying, the pores circular, with thin dissepiments, 3-5 per $\mathrm{mm}$; context 1-3 mm thick, soft and cottony, persistently crème colored; tube layer very thick, up to $20 \mathrm{~mm}$, extremely brittle and shattering easily when dry, crème at first but deep brown when dry and contrasting with crème subiculum. Spore print brown.

Hyphal STRUCTURE monomitic; hyphae with clamp connections, $\mathrm{KOH}-$, IKI-. ConTeXt. Hyphae arranged in subparallel bundles, mostly thin-walled, $4-10 \mu \mathrm{m}$ in diam., some hyphae with thick-walls and refractive, hyaline or pale
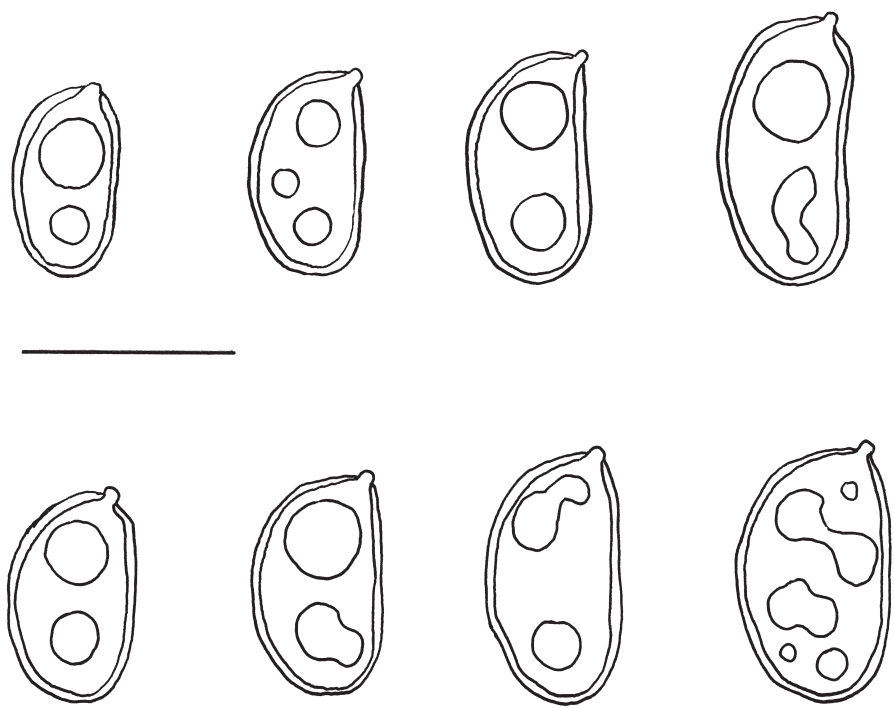

FIGURE 2: Sarcoporia basidiospores: above - S. longitubulata (holotype); below $-S$. polyspora (lectotype). Scale bar $=5 \mu \mathrm{m}$. 


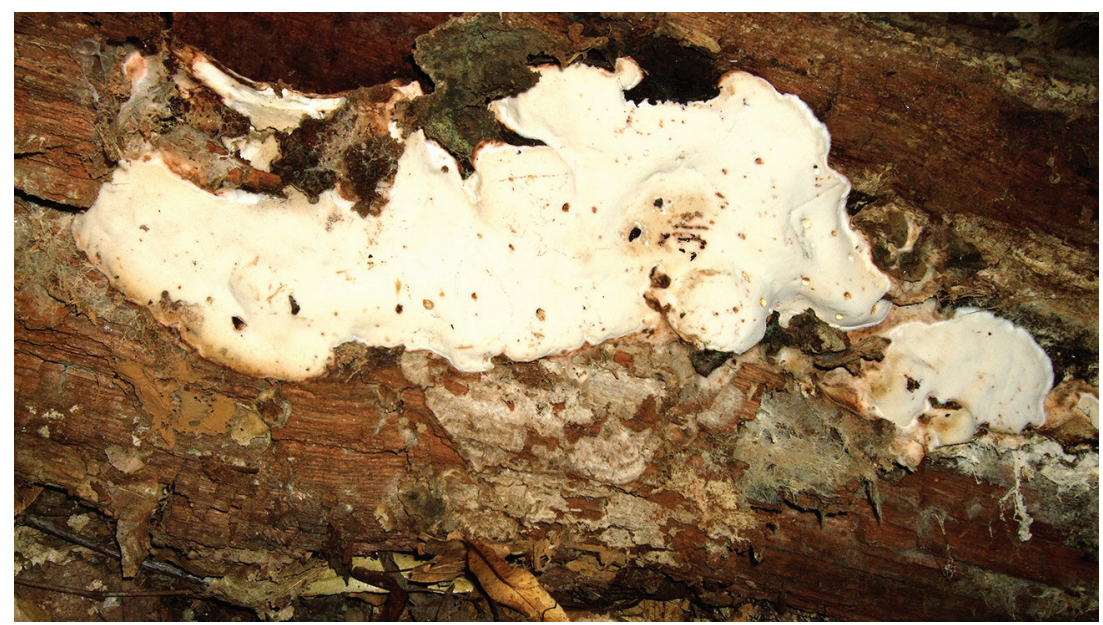

FIgURE 3: Sarcoporia longitubulata (JV 0809/8, holotype), underside of oak log, photo in situ. Spore deposits below left.

brown, with cyanophilous content, strongly inflated at septa, 7-18(-22) $\mu \mathrm{m}$ in diam., occasionally with double clamps. Tubes. Hyphae subparallel, rather loosely arranged, thin-walled, hyaline, easily collapsing, some with cyanophilous content, (3.5-)4-5(-6) $\mu \mathrm{m}$ in diam. Cystidia absent. BAsidiospores thickwalled, brownish, oblong-ellipsoid, ventral side slightly concave or rarely flat, dextrinoid, a few spores weakly or moderately cyanophilous, (4.3-)4.4-6.2 $(-7.2) \times(2.3-) 2.5-3.3(-3.5) \mu \mathrm{m}(\mathrm{n}=150 / 5), \mathrm{L}=5.29, \mathrm{~W}=2.88, \mathrm{Q}=1.78-1.93$.

Distribution \& ECOlOgY. On hardwood logs (predominantly Quercus spp.) in the US North-East (Michigan, New York, Pennsylvania, Tennessee) and Macaronesia (Madeira Is.); causing a brown rot.

Additional specimens examined: PORTUGAL. Madeira: Madeira Island, $3 \mathrm{~km}$ W from Funchal, fallen angiosperm logs, 19 Jan 2011, Kinnunen 5837 (H, GenBank KM207865), 5845, 5848 (H). USA. Pennsylvania: Gettysburg, Big Round Top, Quercus, 5 Sep 2010, Vlasák JV 1009/9A (JV, H, GenBank KM207861, KM207862, KM207864). Michigan: Ann Arbor, hardwood, Jul 1958, Wehmeyer (BPI 223824). New York: Rye, Quercus, 30 Oct 1980, Stein (BPI 222859). TennesseE: Great Smoky Mt., New Found Gap, Fagus, 9 Sep 2005, Vlasák JV 0509/103 (JV, H).

Comments. Macroscopically, S. longitubulata is very distinct, so that we felt certain from first glance that it must be a different species (FIgs 3, 4). The brown spore deposits around the basidiocarp, the very long and soft tubes, and the relatively thin subiculum lacking a cartilaginous layer are its most striking morphological features. Sarcoporia polyspora produces white spore deposits and more or less pileate basidiocarps with short tubes and a thick subiculum containing a distinct cartilaginous layer. We noted no odor of fresh 


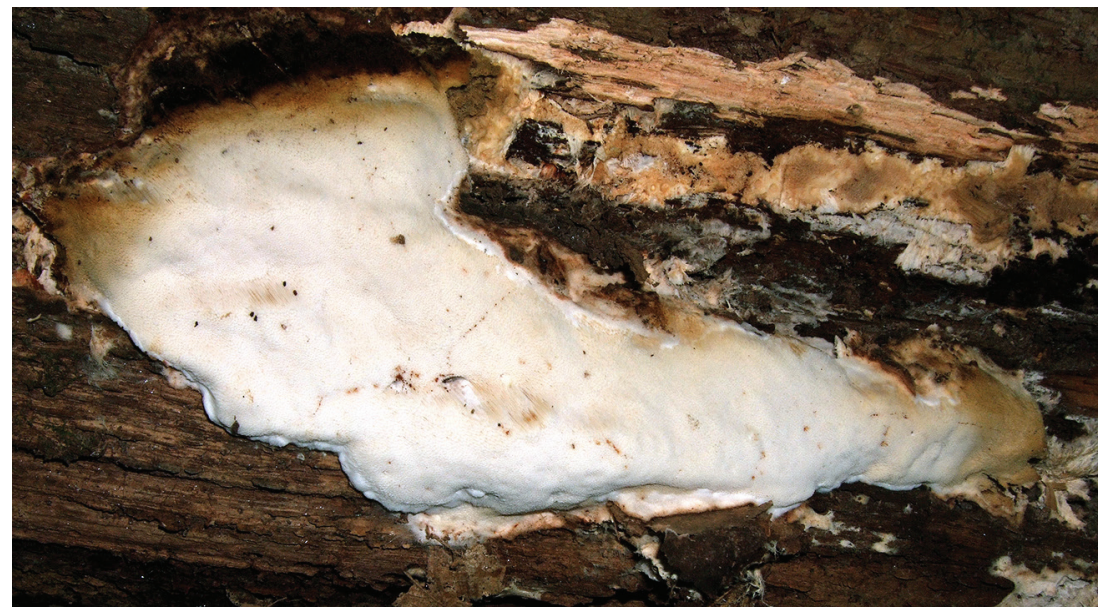

FIGURE 4: Sarcoporia longitubulata (JV 0809/8, holotype), underside of oak log, photo in situ.

basidiocarps, but on drying, S. longitubulata smelled so repugnantly that it was impossible to keep in the same room for more than one week, although it was not contaminated with yeasts. The primary microscopic difference of $S$. longitubulata is the pale brown coloration of the basidiospores, visible in cotton blue even with low resolution; only a few spores are more or less stained (slightly or moderately cyanophilous). In contrast, S. polyspora basidiospores are exceptionally strongly cyanophilous (uniformly bright blue), so that their natural color is totally undetectable in cotton blue. Moreover, the S. longitubulata spores are a bit narrower than in S. polyspora (TABLE 1) and less variable in shape and size, being uniformly oblong-ellipsoid and slightly concave on their ventral side (FIG. 2). The basidiospores of this type occur in S. polyspora, too, but only as a rare variation.

\section{Discussion}

We have shown that $S$. polyspora is widely distributed from America to Europe and Far East Asia. The slight morphological differences we observede.g., longer spores and more pileate habit in USA collections vs. shorter spores in Far East Asian collections-have no support in DNA sequence differences and so should be regarded as regional morphological variation. A tropical distribution remains uncertain, as the sequenced specimens from Brazil were collected from Pinus logs probably imported from the USA (Baldoni et al. 2015).

All studied collections were from conifers except for BPI 844703, the type of Polyporus transmutans (Overholts 1952), collected on Prunus serotina Ehrh. in northwestern USA. This specimen displays strikingly large and tough pilei with 
TABLE 1. Spore measurements of two Sarcoporia species. (Limit and mean values for each species shown in bold.)

\begin{tabular}{lllllll}
\hline SPECIES / SPECIMEN & $\mathrm{L}^{\prime}$ & $\mathrm{L}$ & $\mathrm{W}^{\prime}$ & $\mathrm{W}$ & $\mathrm{Q}$ & $\mathrm{n}$ \\
\hline S. polyspora & $(4.2) 4.7-7.2(7.3)$ & 5.53 & $(2.5) 2.6-3.8(4.0)$ & 3.10 & 1.79 & 270 \\
Miettinen 14814 & $(5.0) 5.1-6.3(6.7)$ & 5.64 & $(2.7) 2.8-3.6(4.2)$ & 3.14 & 1.81 & 30 \\
Spirin 4420 & $(4.9) 5.0-6.3(6.7)$ & 5.51 & $(2.7) 2.8-3.2(3.3)$ & 2.97 & 1.86 & 30 \\
Spirin 5201 & $(4.2) 4.7-5.7(5.8)$ & 5.05 & $(2.6) 2.7-3.3$ & 3.02 & 1.68 & 30 \\
Spirin 5422 & $(4.7) 4.8-5.7(7.1)$ & 5.22 & $(2.5) 2.6-3.2(3.3)$ & 2.93 & 1.79 & 30 \\
Spirin 6021 & $(4.8) 5.2-6.8(7.3)$ & 5.70 & $(2.6) 2.7-3.6(3.7)$ & 3.07 & 1.86 & 30 \\
Spirin 6018 & $(4.8) 4.9-6.1(6.2)$ & 5.30 & $(2.7) 2.8-3.4(3.7)$ & 3.11 & 1.71 & 30 \\
Vlasák 0908/15 & $(4.8) 5.0-6.2(6.4)$ & 5.56 & $(2.7) 2.8-3.7(3.9)$ & 3.17 & 1.76 & 30 \\
Vlasák 0309/93 & $(5.2) 5.3-7.2(7.3)$ & 6.27 & $(2.8) 2.9-3.8(4.0)$ & 3.19 & 1.97 & 30 \\
S. longitubulata & $(4.3) 4.4-6.2(7.2)$ & 5.29 & $(2.3) 2.5-3.3(3.5)$ & 2.88 & 1.84 & 150 \\
Vlasák 0809/8 & $(4.3) 4.4-5.8(6.0)$ & 5.03 & $(2.6) 2.7-3.1(3.3)$ & 2.82 & 1.79 & 30 \\
Vlasák 1009/9a & $(4.6) 4.8-6.2(6.3)$ & 5.42 & $(2.3) 2.5-3.2(3.3)$ & 2.82 & 1.93 & 30 \\
Vlasák 0509/103 & $(4.4) 4.8-5.8(7.2)$ & 5.30 & $(2.7) 2.8-3.3(3.5)$ & 2.97 & 1.78 & 30 \\
BPI 222859 & $(4.8) 4.9-6.2(6.7)$ & 5.39 & $(2.6) 2.7-3.2(3.3)$ & 2.90 & 1.86 & 30 \\
BPI 223824 & $(4.8) 4.9-6.0$ & 5.32 & $(2.5) 2.6-3.3(3.4)$ & 2.91 & 1.83 & 30 \\
\hline
\end{tabular}

short tubes and thick context in which no distinct gelatinous layer is present but scattered gelatinous streaks are present. This suggests just a very large specimen of S. polyspora and our examination revealed no distinct microscopic differences from other S. polyspora specimens. Moreover, the ITS sequence of the culture derived from this specimen available in GenBank (KC585392; Ortiz-Santana et al. 2013) is identical with other S. polyspora sequences.

When we sought for a possible existing name for S. longitubulata, Tyromyces mollissimus Maire, described from North Africa (Maire 1945) and presently regarded as a synonym of $S$. polyspora, seemed a reasonable candidate. Unfortunately, the type material is now unavailable (Pouzar 1984, Kotiranta 1998). Nevertheless, the protologue of T. mollissimus is very clear and leaves no doubts about its identity: it was described as growing on Pinus halepensis Mill. and having pileate or effused-reflexed, very soft basidiocarps with thick contextual layer (see fig. 7b, Maire 1945: 37), and a white spore print. All these features fit well with the current concept of S. polyspora and certainly rule out our new species. The recently described Sarcoporia neotropica from Costa Rica (Ryvarden 2013) has imbricate soft basidiocarps and hyaline basidiospores, characters that preclude its identity with S. longitubulata.

Because of similar spores and some of tissue features, Ryvarden \& Melo (2014) speculated about Sarcoporia's position in the Coniophoraceae. Molecular phylogeny refutes this hypothesis, however. The sequences of typical 
coniophoraceous species such as Coniophora puteana (Schumach.) P. Karst. and Serpula lacrymans (Wulfen) J. Schröt. differ greatly from Sarcoporia, which has already been recognized as a member of "antrodia clade" within the Polyporaceae, most closely related to Amylocystis and Auriporia (OrtizSantana et al. 2013). Amylocystis lapponica (Romell) Bondartsev \& Singer, is in fact quite similar, being soft and turning reddish brown after bruising and drying, causing a brown rot, and with some microstructures staining in Melzer's reagent. Bondarcevomyces taxi (Bondartsev) Parmasto, which was once referred to Parmastomyces (= Sarcoporia in current sense) by Dai \& Niemelä (1995), belongs to the Boletales (Binder \& Hibbett 2006). It does share some characters with S. longitubulata (brownish spores, strong pungent odor of drying basidiocarps) although they indicate only superficial similarity.

AdDitional MATERIAL EXAMINED: Sarcoporia polyspora. CZECH REPUBLIC. Hluboká, Karluv Hradek, Picea abies, 2 Sep 2009 Vlasák JV 0909/1 (JV, GenBank KM207858, KM207859), 11 Aug 2009, Vlasák JV 0908/15 (JV, PRM 915664, H). FINLAND. UusimaA: Inkoo, Fagervik, Sept 1893, Hisinger (H) (lectotype of S. polyspora; Lowe 1956). RUSSIA. Khabarovsk Reg.: Khabarovsk Dist., Ulika, Pinus koraiensis, 13 Aug 2012, Spirin 5201 (H, GenBank KM207856, KM207857), Malyi Kukachan, Picea ajanensis, 19 Aug 2012, Spirin 5422 (H, GenBank KM207852); Solnechnyi Dist., Evoron, Picea obovata, 27 Aug 2011, Spirin 4420 (H, GenBank KM207853). NizHNy Novgorod Reg.: Lukoyanov Dist., Panzelka, Pinus sylvestris, 8 Aug 2013, Spirin 6018 (H, GenBank KM207851), Picea abies, 8 Aug 2013, Spirin 6021 (H, GenBank KM207854, KM207855). USA. MAssaChusetts: Holden, Quinapoxet, Tsuga canadensis, 26 Sep 2011, Miettinen 14814.1 (H, GenBank KM207850). Pennsylvania: Wilkes-Barre, Ricketts Glen St. Park, Pinus, 11 Sep 2003, Vlasák JV 0309/93 (JV, H, GenBank KM207849); Haycock, Nockamixon St. Park, Pinus strobus, 7 Aug 2004, Vlasák Jr. JV 0408/4J (JV); McKean Co., Prunus serotina, 10 Sep 1940, Campbell \& Davidson 22971 (BPI 844703, holotype of Polyporus transmutans, GenBank KC585392). New York: Adirondack Park, Keene Valley, Johns Brook Trail, conifer, 23 Sep 2005, Vlasák Jr. JV 0509/193J (JV).

Bondarcevomyces taxi. RUSSIA. Khabarovsk Reg.: Khabarovsk Dist., Bol'shoi Khekhtsir Nat Res., Picea ajanensis, 5 Sep 2013, Spirin 6674 (H, JV); Komsomol'sk Dist., Boktor, Larix gmelinii, 18 Aug 2013, Spirin 6141 (H, JV).

\section{Acknowledgments}

The authors thank the BPI herbarium staff for the kind loan of Sarcoporia specimens, Dr. Otto Miettinen for sequencing the Kinnunen 5837 specimen, and Prof. Teuvo Ahti for revising the Latin diagnosis. Valuable discussions with Jiri Kout, G. Coelho, and Y.-C. Dai and their contributions as presubmission reviewers are acknowledged. The research of J. Vlasák was funded by institutional support RVO: 60077344 .

\section{Literature cited}

Baldoni DB, Ortiz-Santana B, Coelho G, Antoniolli ZI, Jacques RJS. 2015. Sarcoporia polyspora (Basidiomycota, Polyporales): a rare wood-decay fungus newly recorded from South America. Nova Hedwigia 100: 177-187.

http://dx.doi.org.ezproxy.landcareresearch.co.nz/10.1127/nova_hedwigia/2014/0218 
Binder M, Hibbett DS. 2006. Molecular systematics and biological diversification of Boletales. Mycologia 98(6): 971-981. http://dx.doi.org/10.3852/mycologia.98.6.971

Dai YC. 2012. Polypore diversity in China with an annotated checklist of Chinese polypores. Mycoscience 53: 49-80. http://dx.doi.org/10.1007/s10267-011-0134-3

Dai YC, Niemelä T. 1995. Changbai wood-rotting fungi 4. Some species described by A.S. Bondartsev and L.V. Lyubarsky from the Russian Far East. Annales Botanici Fennici 32(4): 211-226.

Karsten PA. 1894. Fragmenta mycologica XLII. Hedwigia 33: 15-16.

Kotiranta H. 1998. Parmastomyces mollissimus in North Europe. Folia Cryptog. Estonica 33: 41-47.

Kotlaba F, Pouzar Z. 1964. Staining spores of Homobasidiomycetes in cotton blue and its importance for taxonomy. Feddes Repert. 69: 131-142.

Maire R. 1945. Etudes mycologiques. Fascicle 5. Bull. Soc. Hist. Nat. Afr. N. 36: 24-42.

Miettinen O, Niemelä T, Spirin W. 2006. Northern Antrodiella species: the identity of A. semisupina, and type studies of related taxa. Mycotaxon 96: 211-239.

Niemelä T, Kinnunen J, Larsson KH, Schigel D, Larsson E. 2005. Genus revisions and the new combinations of some North European polypores. Karstenia 45: 75-80.

Ortiz-Santana B, Lindner DL, Miettinen O, Justo A, Hibbet DS. 2013. A phylogenetic overview of the antrodia clade (Basidiomycota, Polyporales). Mycologia 105: 1391-1411. http://dx.doi.org/10.3852/13-051

Overholts LO. 1941. New species of Polyporaceae. Mycologia 33: 90-102. http://dx.doi.org/10.2307/3754741

Overholts LO. 1952. New species of polypores. Mycologia 44: 224-227.

Parmasto E. 1957. Eesti seente eksikaat. Mycotheca Estonica 1: no. 1-25. Tartu. 22 p.

Pouzar Z. 1984. Notes on four European polypores. Česka Mykol. 38: 203-204.

Ryvarden L. 2013. Studies in neotropical polypores 32. Some new species from Costa Rica. Synopsis Fungorum 30: 33-43.

Ryvarden L, Gilbertson RL. 1984. Type studies in the Polyporaceae 15, species described by O.L. Overholts, either alone or with J.L. Lowe. Mycotaxon 19: 137-144.

Ryvarden L, Melo I. 2014. Poroid fungi of Europe. Synopsis Fungorum 31: 1-455

Tamura K, Stecher G, Peterson D, Filipski A, Kumar S. 2013. MEGA 6: Molecular Evolutionary Genetics Analysis version 6.0. Mol. Biol. Evol. 30: 2725-2729. http://dx.doi.org/10.1093/molbev/mst197

Vlasák J, Kout J. 2010. Sarcoporia polyspora and Jahnoporus hirtus: two rare polypores collected in South Bohemia, Czech Republic. Czech Mycol. 61(2): 187-195.

Vlasák J, Kout J. 2011. Tropical Trametes lactinea is widely distributed in the eastern USA. Mycotaxon 115: 271-279. http://dx.doi.org/10.5248/115.271 